\title{
Legal Regulation Systems of Deposit Insurance: International Practice and Local Expertise
}

\author{
Yuri Alexeyevich Kolesnikov
}

Southern Federal University, Russian Federation, 344007, Rostov-on-don, street M. Gorky, 88

Igor Petrovich Zinoviev

Southern Federal University, Russian Federation, 344007, Rostov-on-don, street M. Gorky, 88

Alla Vasiliyevna Kiseleva

Southern Federal University, Russian Federation, 344007, Rostov-on-don, street M. Gorky, 88

\section{Doi:10.5901/mjss.2015.v6n6p101}

\section{Abstract}

The article describes the questions of guaranteeing the safety of funds of individuals and legal entities in the Russian banks. First there is an analytical review of such experience in foreign countries in the article. Then the author explores the current status of legislation and practices in the protection of individuals' deposits through the Deposit insurance system. As a result, the author concludes that Russia has a positive experience in protecting the deposits of individuals, although for the duration of this institution there is a need of adjustment. However, the most urgent issue is to guarantee the safety of deposits of legal entities, which, as such, is absent in the Russian practice. In this regard, the author proposes to implement legislative initiatives.

Keywords: bank deposits, deposits, guarantees, banks, insurance, individuals and legal entities.

\section{Introduction}

Ensuring the safekeeping of funds of legal entities and physical persons in banks of the Russian Federation and around the world is the most important task of the global banking system. To solve this problem, as you know, there are a number of guarantee systems and methods of Deposit insurance. Thus, according to the methodology, which was adopted by the International Monetary Fund, these systems may be divided into two groups: a safeguards system that is not directly expressed, and the system of warranties, expressed positively (Tikhomirov, 2014).

The first of the above systems are used in countries in which more often than not there is specific legislation and other normative acts, which in the case of bankruptcy of a Bank regulate the procedure, shapesand sizes damages to its depositors. There is no practice of creating a special Fund that would compensate these damages is not only clear the obligations of the state or other bodies regarding the safety of public funds invested in banks (Zemlyanskaya, 2014). Consequently, each case of compensation of losses is considered by the state separately, as well as the order of payments on it.

As for systems with warranties, expressed positively, its basic principles and fundamental differences from the above-described system are the guarantee of return of Bank deposits, established by law, as well as specially formed for these purposes Fund.

This article is devoted to the topical, especially in the new economic environment, the Institute of guaranteeing the deposits of individuals and legal entities in the Russian banks. The aim of this work is the analysis of the deposit insurance system in Russian Federation in the current situation, the designation of the problems and prospects of its development and in this regard, the proposal to implement a number of legislative initiatives. Special attention is paid to the detail examination of such aspects as identifying features of the deposit insurance system in Russian Federation and to the analytical review of Deposit insurance in foreign countries. 


\section{Method}

In the process of preparing of this articlethere were used theoretical and special scientific methods of knowledge, such as: analysis, synthesis, logic, dialectic, a method of comparative law, the method of expert evaluations. The generalizations and conclusions have been done.

It has been analyzed that the system of Deposit insurance in each country due to different national conditions implies certain characteristics, based on differences in the structure of institutions, ways of building the system, the possibilities concerning the coverage of credit institutions, which work with deposits, as well as in the procedure for the establishment of insurance funds. In some countries, only one Institute manages the entire warranty system. In other countries, each institution of the system of protection of savings is controlled by the private sector, which includes the institution of a particular type (Kudryashov, 2014).An overview of the features of Deposit guarantee in the world is provided, which allows us to better reflect and introduce the peculiarities of the situation in Russia to the reader. Through the use of the method of comparative analysis, it becomes possible to draw conclusions about the similarities and differences in these aspects. In line with this, some conclusions are drawn, on the basis of which, in turn, some practical recommendations are deduced.

\section{Results}

\subsection{World practice}

An important criterion to ensure the safety of funds is the form of Deposit insurance. There are forms of compulsory and voluntary insurance. Compulsory form provides for conditions of insurance, which are established legislatively in the number of the subjects and objects of insurance, determining insurance premiums (such a system operates in the USA, Canada, the UK, the Netherlandsand Japan) (Alekseev and Pykhtin, 2014). Voluntary form of insurance is characterized by self-acceptance of each Bank's decision about whether he will be to participate or not to participate in insurance. However, banks typically find themselves in conditions of forced existence insurance coverage, because the Bank is not participating in the insurance system, loses in the competition (described system exists in France, Germany, Italy) (Sergeev, 2014). In both cases, insurers may act both public and private and mixed organizations. State organizations are formed, as a rule, in a situation of compulsory insurance. Then operations are performed by the public body, created specifically with the described purpose, without profit. For capital formation such insurance organizations can be used state funds in addition to contributions from banks (the USA) (Akramov, 2014).In Germany, France, Luxembourg, the insurance is carried out by organizations established as part of the Association of banks, the state in the activities of such funds does not interfere into their lending system. Funds managed by these banks Association, the formation of their resources occurs only from the contributions of the participating banks. In addition, there is a mixed form of guarantee organizations. In this case, the creation of authorized capital occurs with the help of state authorities and commercial structures (e.g., Japan) (Belov, 2009).

As objects of insurance coverage may be the deposits of physical persons and legal entities (either physical only); deposits only in national or in foreign currency; deposits residents only or including the contributions of non-residents. Under the insurance cover may fall as soon as the local banks, and local and foreign banks operating in the country; as well as only valid in the country banks, or including branches of domestic banks abroad.

In world practice, guarantee funds traditionally are formed in two different ways. In the first case, the date of occurrence of Bank failure other system members seeking funds intended for payments to depositors of the bankrupt, immediately after the announcement of bankruptcy. This option of capital collection is typically used in private Deposit insurance schemes, which are managed by their members. As the main drawback of the described embodiment can be described no solid guarantee that you will have funds intended for settlement. For example, when the insured event occurs in several banks at the same time, you may find that other participants in the system have no necessary funds for the purposes of establishing compensation Fund contributions urgently. Built system, according to this principle, involves difficulties in the appointment of the size of the required fees, as necessary information about the state of finances and the risks taken by banks, in the situation described there.

The second variant of forming guarantee funds is the formation of a special Fund through contributions regularly. This Fund is at the disposal of the managing organization; payment amounts are produced in a matter of urgency, to ensure the participation costs of all participants in the system; load arising from the need to compensate for the deposits in case of closure of insolvent banks, for participants in the system is distributed over time. The formation of resources of such institutions is due to the contributions of credit institutions (usually the entrance fee and recurring payments ranging 
relative to deposits), loans, monetary authorities and international financial institutions (Kalitov, 2014). Regular contributions of credit institutions can be in the range from $0,008 \%$ in Japan and up to $0,3 \%$ of the amount of obligations in the UK (Vishnevsky, 2000).

\subsection{Russian practice}

In the practice of the Russian Federation in the real time system to ensure the safety of funds of physical persons in banks of the Russian Federation operate on the basis of the Federal Law dated 23.12.2003 N 177-FZ (as amended on 29.12.2014) "On insurance of deposits of individuals in banks of the Russian Federation". Government financial guarantees, which protect and ensure the implementation of constitutional rights and freedoms of man and citizen, such as the right of property, including cash, implemented by the Deposit guarantee system of the Deposit Insurance Agency (hereinafter referred to as the DIA). Namely, in order to ensure the functioning of the Deposit insurance Agency is the payment to the depositors of the compensations in case of insured event; maintains the register of banks-participants of the Deposit insurance system(hereinafter referred to as the DIS); monitors the formation of the Deposit insurance Fund, including contributions from the banks; the management of the Deposit insurance Fund (Tychynin and Romanenko, 2013).

Currently, the Law requires mandatory participation in the DIS from all banks that have the right to attract public funds deposits. Monetary means of citizens are insured from the moment of inclusion of the Bank in the register of members of the DIS. According to the current legislation (Federal law dated 23.12.2003 No. 177-FZ (as amended on 29.12.2014) "On insurance of deposits of individuals in banks of the Russian Federation") the insurance covers the deposits of natural persons in the amount of up to 1,400,000 rubles, and from 01.01.2014 and contributions of individual entrepreneurs associated with commercial operations. Until December 29, 2014, in accordance with the draft law No. 298254-6, conditions guaranteeing state security funds were such that if the depositor several deposits in the same Bank, the compensation effected on each deposit with regard to their size, but not more than $1,000,000$ rubles in total. Currently in a similar situation, the total payout is up to 1,4 million rubles. In accordance with the text of the law on compensation in the amount of up to 1,4 million rubles will be able to count only the depositors, insured event in respect of which comes after the entry into force of the law. However, there are some exceptions, under which the insurance is not all the funds of individuals, placed in deposits in member banks of the DIS. So, the insurance of deposits of physical persons shall not apply to funds on the accounts of lawyers, notaries, deposits payable to bearer on funds given to banks in trust; to deposits in foreign branches of Russian credit institutions, electronic money (Maharjan, 2014).

The decision to increase the amount of compensation was taken after a sharp depreciation of the ruble. Over the past three months, the dollar's rate grew by almost two thirds, resulting in many previously open foreign currency deposits ceased to fit in the amount of 700,000 rubles. If on September 1 contribution of $\$ 15,000$ was equivalent to approximately RUB the 560,000 , today it is equivalent to about 800,000 rubles, and to receive full compensation from the DIA is impossible. Thanks to changes in Federal law dated 23.12.2003 No. 177-FZ (as amended on 29.12.2014), were introduced measures aimed at reducing risks to the DIS, and identified the sources of deficit financing Fund of compulsory insurance of deposits.In addition, at present is already known that the DIA seeking opportunities for improvement guarantee instruments. Improvements will address what are considered the prospects for the introduction of guarantees irrevocable personal certificates in addition to the existing guarantees on deposits up to 1400000 rubles. The Ministry of Finance has been proposing for two years to introduce in the law the term "irrevocable personal certificate" and to consider how to increase the attractiveness of this instrument for investors. At the moment the guarantee certificate for a period of one year are assumed to be in the amount of 1 million rubles, from two years in the amount of 2 million rubles, from three years -3 million, respectively. Definitely, guarantee terms will differ from those on deposits, but higher warranty certificate, according to bankers, no one will infringe. But in this situation it is necessary revision of such a moment: there is a risk, consisting of a mercenary of some participants who might try to raise funds from the market under warranty of the DIA using high interest rates (Efremova et al., 2010).

\subsubsection{Statistics and Data Analysis}

The state corporation "Deposit Insurance Agency" (DIA) as a non-profit organization and a model Institute for financial market regulation, generally accepted in international practice, operates in Russia since November 2004. Since the establishment of the DIA 1348,2 thousand depositors received insurance indemnity in the amount of 385,9 billion rubles (data as of 1 February 2015). According to statistics as of 18 February 2015 in the DIS 858 registered banks, including 684 operating banks licensed to work with individuals, 8 of operating credit institutions, which were formerly deposits, but 
without the right to attract monetary means of natural persons, 166 of banks in process of liquidation. As on February 2 , 2015 , the size of the Fund of obligatory insurance of deposits is 77,7 billion rubles (net of the provision for payments for insured events occurred $-63,7$ billion rubles). During the time of the DIS 220 insurance claims occurred. The insurance liability of the DIA by banks in respect of which the insured event occurred, is 390,2 billion rubles. The number of depositors who are entitled to the insurance indemnity in the banks in which the accident occurred, is 3478,3 thousand people (all of the above as at 1 February 2015) .

Speaking of the process of liquidation of banks in the system DIS, it should be noted that at the present time, the Agency performs the functions of a bankruptcy Trustee (liquidator) in 184 credit institutions. In these credit institutions 237331 (data as of February 13, 2015) creditors, the amount of claims which is 737287,81 million rubles (February 13, 2015). Since its launch in November 2004, the Agency implemented 211 completed liquidation procedures of the banks, just for this time registered 395 these procedures. On October 27, 2008 it was adopted Federal law No. 175-F3 "On additional measures to strengthen stability of the banking system in the period until 31 December 2014", according to which the Agency has been vested in another, and the functions of financial rehabilitation of banks. Thus, upon expiration of the specified period, the Agency participated in the 27 Bank rehabilitation projects.

Returning to the current situation, let's recall that in the case of revocation of the license of the Bank, depositors receive compensation from the DIA. When this rule first appeared, it was prescribed number of 100 thousand rubles. Since 2008 the amount of insurance compensation on deposits amounted to 700,000 rubles. Now this figure has doubled, to 1400000 rubles. Over the years, there are several factors that determine the need to change the size of insurance payments. Among these factors the cumulative inflation. The consequence of inflation is the fact that the objective level of protection of depositors is deteriorating. Another factor is that in recent years the income of the population increased by $50 \%$. This entails a gradual escalation of contributions. It is important to note that the consequence of the global crisis of 2008 was the increase of guarantees on deposits as a preventive measure to maintain the stability of the banking sector. To date, investors in Russia are protected significantly less than not only in economically developed countries, but also in a number of the CIS countries (Azerbaijan, Kazakhstan). International practice suggests that a comparison of insurance compensation by comparing it with the size of GDP per capita. Until 2007-2008 this value in insurance was measured 1-2 shares of GDP per citizen. As a consequence of the crisis, this indicator is now measured $3-5$ shares of GDP per person. The insurance indemnity in the Russian Federation has a size of 1,7 share of GDP for 2011 per capita that is at the lower boundary of the range of global indices.

\section{Discussion}

Simultaneously, interest rates on deposits offered by banks are the main asset in the competition for customers, which have deposits, suggesting under the present system of Deposit insurance, the maximum amount of insurance compensation. You should not overlook the existence of risk redistribution of deposits in potentially insolvent banks, which entice the population of high interest on deposits. In light of the above Law the increase of contributions to the compulsory Deposit insurance for credit institutions, if their policy creates increased risks to the DIS as financial measures, limiting the possible strengthening of this risk.

According to the amendments from 22.12.2014 N 432-FZ, as amended in Federal law dated 23.12.2003 No. 177$\mathrm{FZ}$, the new base rate is set at not more than $0,15 \%$ of the calculation base for the last billing period. In cases stipulated by the Federal law, the base rate may be set at levels up to 0,3 percent of the calculation base, but to act this rate will be not more than for 2 billing periods in the next 18 months. The base rate of insurance contributions is the same for all banks size and required to be paid for all banks. Additional insurance premium rate may be determined in the amount of not more than 50 percent of the base rate and also the same for all banks. To determine which banks will be required to pay an additional rate or increased an additional bet, the Bank of Russia provides for the definition of the base level of profitability as for deposits, which are involved in Russian rubles and foreign currency deposits, calculating the average rate of reported to an unlimited circle of persons maximum interest rates on deposits in banks that were involved in total, two-thirds of the total volume of household deposits in banks of the Russian Federation, in respect of contributions corresponding to those conditions, which were defined by the normative acts of the Bank of Russia as of the conditions of the calculation of the baseline level of Deposit yields.

The indicated rate of return on deposits in Russian rubles and in foreign currency on a monthly basis is calculated in the manner prescribed by regulatory acts of the Bank of Russia (Gusev, 2014). The Bank of Russia relays this information to the general public and to the banks not later than 3 working days prior to the beginning of each month. In case of the need to find additional sources of funding, and the deterioration of the economic situation or deficit of the Fund of obligatory insurance of deposits, the bill gives the Board of Directors of the state corporation "DIA" the right to 
appeal to the Bank of Russia with a request to provide credit without collateral for up to five years. The repayment of this loan is provided from funds for future contributions to the Deposit insurance Fund. Article 41 of the Federal law envisages the possibility of using Agency funds Fund of obligatory insurance of deposits for the performance of obligations under the loan provided by the Bank of Russia.

Considering the actual condition of systems to ensure the safety of funds of physical persons in banks of the Russian Federation, it is necessary to mention that today in the compensation funds of the DIA remained amount to 77,7 billion (as of February 2, 2015), less the liabilities of the troubled banks to depositors at the beginning of the current year (Barenboim, 2010). Russia entered the recession and it is expected new problems in the banking system. The state decided on the increase of capital of individual banks, however, these measures are obviously not enough.

That's why we can call the accession of the current state of the law and practice of its implementation in the protection of retail deposits through the deposit insurance system in DIA the novelty of the research. The specific contribution of the author in the research is to identify ways of further improvement and development prospects of the deposit insurance system in Russian Federation. The practical significance of the research is to develop science-based regulations, conclusions, recommendations for improving the effectiveness of the system of guaranteeing deposits in Russian Federation and the designation of the development prospects of the Russian banking system.

\section{Conclusions}

As one of the most important conclusions it seems necessary to mention the situation in respect of deposits of legal persons, and the prerequisites for the further development of the Institute of banking insurance and legal perspectives in this direction. In accordance with the provisions of the Civil Code of the Russian Federation reimbursement of deposits of legal persons held in the sixth (last) place, which negates the very possibility of obtaining such insurance compensation. Federal law "On insolvency (bankruptcy) of credit organizations" adopted 25.02. 1999 № 40-FZ, also not aimed at the real protection of interests of depositors - legal persons. These factors are the most important preconditions for improvement of the Institute of insurance of Bank deposits. As the following factors are global systemic financial and economic crisis and its consequences in Russia; the need to ensure the attractiveness of deposits for legal entities and improve the solvency of banks for development of entrepreneurship; the revocation of licenses for banking activities as a result of the severe policy of banking supervision of the Central Bank of the Russian Federation, which sees its role only in the revocation of licenses, not caring about the interests of depositors; different effects of Bank failures for different categories of depositors and customers of banks and different types of assets. Thus, in light of the above, the following practical recommendations are presented strongly needed:

1. to prepare a legislative initiative in the State Duma of the Russian Federation on the adoption of the Federal law "On insurance funds of legal persons in banks of the Russian Federation", and during the development of this initiative:

- to provide for the replacement of allocations of banks funds of required reserves contributions to insurance funds, giving the DIA functions in their formation, distribution and use in case of revocation of the license of the Bank or the introduction of bankruptcy procedures;

- to determine the mechanism of insurance of financial risks as required under attracting deposits from individuals and legal entities;

2. it is necessary to legally define strict requirements and criteria for the competitive selection of credit institutions funds of state and municipal organizations, institutions and other "legal entities of public law" through the development, legal consolidation and implementation in practice of methods of rating estimates using as the basis of the financial and economic assessments of credit institutions by the Bank of Russia;

3. further improvement of banking supervision, increase its efficiency, the increase of capital of systemically important banks with large volumes of attracted deposits and consumer lending on the basis of objective criteria such banks;

4. it seems reasonable to take measures to increase the confidence of depositors to banks by further increase of the limit of insurance coverage of deposits up to 3000000 rubles as a temporary measure for the period of the economic crisis and the provision of Central Bank of the Russian Federation to the DIA, loans or other forms of financial assistance in accordance with the Federal law on insurance of deposits for the purpose of stabilizing the situation on the market of Bank deposits and guarantee their safety. 


\section{References}

Akramov, T. R. (2014). Modern system of Deposit insurance in the USA. (Vol. 1, pp. 52-60). Banking Law.

Alekseev, D. G. and S. V. Pykhtin (2012). Banking Law: textbook. Moscow: Higher education.

Barenboim, P. (2010). The Bill on the reform of the civil code ignores the interests of Russian investors and global experience of crisis in financial markets. (Vol. 11). Law and Economics.

The Civil code of the Russian Federation, part 2, from 26.01.1996 No. 14-FZ (as amended. and DOP.) Collected legislation of the Russian Federation, 30.01.1996, No. 5, p. 410.

Efremova, M. D. et all. (2010). Protection of rights of consumers of financial services. Moscow: Norma, Infra-M.

Federal law dated 25.02.1999 No. 40-FZ (as amended and additional) "On insolvency (bankruptcy) of credit organizations". Collected legislation of the Russian Federation, 01.03.1999, №. 9, p 606.

Federal law dated 23.12.2003 No. 177-FZ "On insurance of deposits of individuals in banks of the Russian Federation" (as amended. and DOP.) // RossiyskayaGazeta, No. 261, 27.12.2003.

Gusev, A. G. (2014). The Bank of Russia as a body for the protection of the rights of consumers of financial services. (Vol. 1, pp. 5-14). Banking Law.

Kalitov, D. E. (2014). Part of the state in the prevention of Bank bankruptcies in Germany. (Vol. 4, pp. 58-69). Banking Law.

Kolesnikov, Y.A. (2013). Constitutional and legal status of the Central Bank of the Russian Federation: the modern transformation under the influence of economic processes. Abstracts of scientific-practical conference "the 20th anniversary of the Constitution of the Russian Federation. Constitutional rights and freedoms of the Russian Federation", Rostov-on-don.

Kolesnikov, Y.A. (2012). The legal status of a mega-regulator and mega supervision in the financial markets as elements of an international financial centre in the Russian Federation (article). Magazine "Problems of law, 4 (35).

Kudryashov, V. V. (2014). Shadow banking as an object of international financial regulation (the Beginning). (Vol. 6, pp. 3-6). Financial law.

Kudryashov, V. V. (2014). Shadow banking as an object of international financial regulation (Concluded). (Vol. 7, pp. 3-10). Financial law.

Maharjan, D. A. (2014). Activities of the state to ensure the stability of the banking system. (Vol. 8, pp. 35-37). Financial law.

Belov, V. A. (2009). Separate financial and legal institutions of foreign countries: Training. textbook. Moscow: PFUR.

Sergeev, S. V. Banking system of Germany and Russia: a comparative legal analysis. (Vol. 5, pp. 56-67). Banking Law.

Tikhomirov, K.A. (2014). Some aspects of legal regulation of the banking system of the Russian Federation. (Vol 8, pp. 43). Financial law.

Tychynin, S. V. and D. I. Romanenko (2013). From Bank guarantee to the independent: the legal nature of commitments to provide guarantees in the draft amendments to the Civil code of the Russian Federation. (Vol. 4, pp. 17-22). Banking Law.

Vishnevsky, A. A. (2000). Right Bank of England. Moscow.

Zemlyanskaya, N.I. (2014). Public law nature of the Deposit insurance Fund. (Vol. 6, pp. 18). Banking Law. 